\title{
Synthesis of a Natural Chromenoquinone via the Diels-Alder Reaction of Pyranobenzyne and Furan
}

\author{
Kazuaki Katakawa, Ayaka Sato, Mari Iwasaki, Tomofumi Horikawa, and Takuya Kumamoto* \\ Department of Synthetic Organic Chemistry, Research Institute of Pharmaceutical Sciences, Musashino University; \\ 1-1-20 Shinmachi, Nishitokyo, Tokyo 202-8585, Japan. \\ Received March 13, 2014; accepted April 28, 2014
}

\begin{abstract}
We describe the total synthesis of angular chromenoquinone 1 isolated from Conospermum plants. Iodophenol, a precursor of pyranobenzyne, was prepared by Claisen rearrangement of an iodoresorcinol derivative. Diels-Alder reaction of the pyranobenzyne and a substituted furan proceeded in low regioselectivity to afford desired 1 and its regioisomer.
\end{abstract}

Key words naphthoquinone; Diels-Alder reaction; furan; benzyne; total synthesis

Quinones are widely found in plants and microorganisms, and show various properties, such as anti-human immunodeficiency virus (HIV), ${ }^{1)}$ antitumor, and antibiotic activities. ${ }^{2,3)}$ Angular chromenoquinones, such as teretifolione $\mathrm{B}^{4)}$ and its trimeric derivative, conocurvone, ${ }^{5)}$ are unique naphthoquinone compounds produced by Conospermum plants. Conocurvone possesses anti-HIV activity. We have reported a simple route for constructing the naphthoquinone core via the Diels-Alder reaction (DAR) of benzyne and a functionalized furan. ${ }^{6}$ ) This led us to investigate the construction of more complex quinone skeletons, which frequently appear in natural products, using unsymmetrical benzyne substrates. In this Note, we describe the application of the DAR approach to constructing the angular chromenoquinone core and the total synthesis of natural chromenoquinone $\mathbf{1}$. The total synthesis of $\mathbf{1}$ starting from naphthalene-2,7-diol was reported as part of the structural elucidation. ${ }^{4)}$

Retrosynthetic analysis in this study is shown in Chart 1. The benzochromene core 1 would be constructed by the DAR of pyranobenzyne $\mathbf{2}$ and substituted furan $\mathbf{3}$. Benzyne precursor 4 would be accessible by Claisen rearrangement of propargyl ether 5. . $^{7}$ Regioselective iodination ${ }^{8)}$ and introduction of the propargyl moiety to commercially available resorcinol monobenzoate $(\mathbf{6})$ would provide $\mathbf{5}$.

Our attempts at the iodination of $\mathbf{6}$ could not reproduce<smiles>[R]C1=C([R])C(=O)c2c(ccc3c2C=CC(C)(CCC=C(C)C)O3)C1=O</smiles><smiles></smiles>

Fig. 1. Representative Natural Chromenoquinones reported regioselectivity, which furnished a 2:1 regioisomeric mixture of iodophenols 7 and $\mathbf{8}$. The structures of 7 and 8 were determined by two dimensional (2D)-NMR analysis. After separation, propargyl group was introduced to 7 in the presence of $\mathrm{Cu}$ (II) catalyst and 1,8-diazabicyclo[5.4.0]undec-7ene $(\mathrm{DBU})^{9,10)}$ by using propargyl ester 9 , derived from alcohol $\mathbf{1 0}$ and trifluoroacetic anhydride (TFAA) in situ, to afford propargyl ether $\mathbf{5}$. The regioselectivity of the thermal Claisen rearrangement of $\mathbf{5}$ was unexpectedly low and a mixture of the desired product 11 and the regioisomer 12 was obtained in a $2: 1$ ratio, ${ }^{11)}$ estimated from the ${ }^{1} \mathrm{H}-\mathrm{NMR}$ integrals. The inseparable mixture of chromenes $\mathbf{1 1}$ and $\mathbf{1 2}$ was hydrolyzed to afford the corresponding phenols $13^{12)}$ and 14 , which were separated by column chromatography. Desired chromene $\mathbf{1 3}$ was treated with $\mathrm{Tf}_{2} \mathrm{O}$ to give benzyne precursor 4 (Chart 2).

The DAR of the pyranobenzyne, derived from 4 , with furan $3^{6)}$ gave a 1:2 isomeric mixture of the desired hydroquinone $\mathbf{1 5}$ and the undesired 16. The structures of $\mathbf{1 5}$ and $\mathbf{1 6}$ were determined by $2 \mathrm{D}-\mathrm{NMR}$ analysis. The solvents used $\left(\mathrm{Et}_{2} \mathrm{O}\right.$, tetrahydrofuran (THF), toluene, 1,2-dimethoxyethane (DME)) did not affect the product ratio. Hydroquinone 15 was oxidized with $\mathrm{FeCl}_{3}{ }^{13}$ ) to quinone $\mathbf{1 7}$ and then debenzylated with $\mathrm{BCl}_{3}$ to give 1 . The spectroscopic data for $\mathbf{1}$ were identical to the literature data. ${ }^{14)}$ The oxidation of its regioisomer $\mathbf{1 6}$ in the same manner gave a complex mixture. Application of (diacetoxyiodo)benzene (DIB)-oxidation in methanol ${ }^{15}$ gave quinone monoacetal 18. Subsequent debenzylation and deacetalization with $\mathrm{BCl}_{3}$ gave 19, the corresponding regioiso-

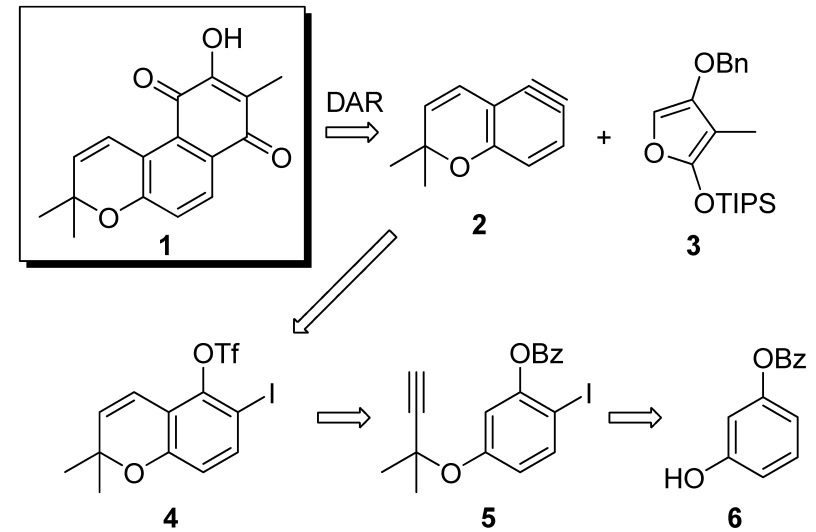

Chart 1. Retrosynthetic Analysis of 1

The authors declare no conflict of interest 


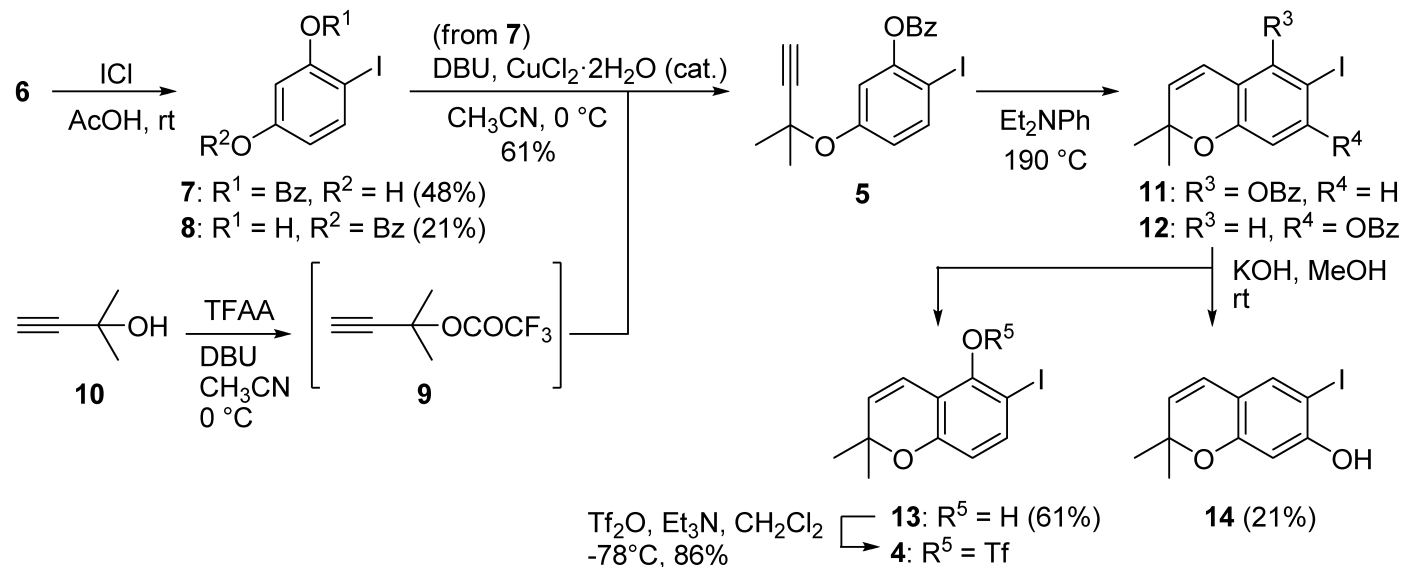

Chart 2. Synthesis of Benzyne Precursor 4

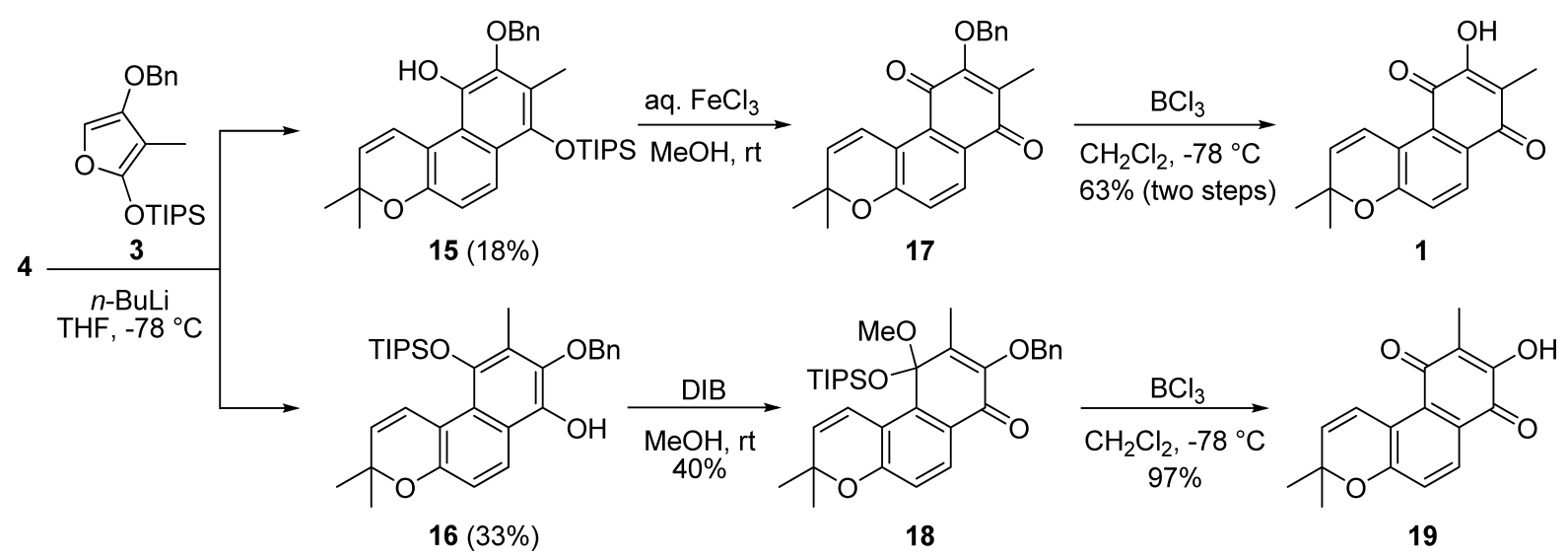

Chart 3. Synthesis of Chromenoquinones 1 and 19

mer of 1 (Chart 3).

We have achieved the total synthesis of natural chromenoquinone $\mathbf{1}$ via the DAR of pyranobenzyne and furan as a key step. The regioselectivity of several steps in this series of transformation is low, which will be improved by further examination. Regioisomer 19 will be useful as a candidate for exploring the structure-activity relationship of this series of chromenoquinones.

\section{Experimental}

General Commercially available reagents and anhydrous solvents were used without further purification. Flash chromatography was carried out with Silica gel $60 \mathrm{~N}(40-50 \mu \mathrm{m})$ from Kanto Chemical Co. IR spectra were recorded on a JASCO FT/IR-4100 spectrophotometer with Attenuated Total Reflectance Unit ATR PRO450-S. Electron ionization (EI)-MS and electrospray ionization (ESI)-MS were recorded on a JEOL GC-Mate II and a Thermo Scientific Orbitrap in positive mode, respectively. ${ }^{1} \mathrm{H}-(400 \mathrm{MHz})$ and ${ }^{13} \mathrm{C}-(100 \mathrm{MHz}) \mathrm{NMR}$ spectra were recorded with JEOL ECX 400 spectrometer with deuterated chloroform as a solvent and tetramethylsilane as an internal reference otherwise noted. Chemical shifts were reported in ppm and $J$ in $\mathrm{Hz}$.

5-Hydroxy-2-iodophenyl Benzoate (7) To a suspension of $6(23.0 \mathrm{~g}, 107 \mathrm{mmol})$ in $\mathrm{AcOH}(108 \mathrm{~mL}), \mathrm{ICl}(7.0 \mathrm{~mL}$, $140 \mathrm{mmol}$ ) was added at $\mathrm{rt}$. After the solution was stirred at $\mathrm{rt}$ for $1 \mathrm{~h}, \mathrm{H}_{2} \mathrm{O}(215 \mathrm{~mL})$ and $\mathrm{Na}_{2} \mathrm{SO}_{3}(4.33 \mathrm{~g}, 34.4 \mathrm{mmol})$ were added. The whole was filtered and the precipitates were washed with $\mathrm{H}_{2} \mathrm{O}$ until the filtrate indicates neutral $\mathrm{pH}$ and dried in air. The crude $(32.3 \mathrm{~g})$ was recrystalized from benzene to yield $7(12.9 \mathrm{~g}$, colorless powder, 35\%). After the mother liquid was concentrated in vacuo, the residue was purified over $\mathrm{SiO}_{2}$ column chromatography (AcOEt$\left.\mathrm{CHCl}_{3}=5: 95\right)$ to give two fractions. Polar fraction $(7.64 \mathrm{~g})$ which included 7 mainly was recrystalized from benzene to give 7 (4.91 g, colorless needles, 13\%) and less polar fraction $(10.7 \mathrm{~g})$ was also recrystalized from benzene to give $8(7.70 \mathrm{~g}$, colorless powder, $21 \%$ )

mp: $163-165^{\circ} \mathrm{C}$. IR: $3330,1708 \mathrm{~cm}^{-1}$. ${ }^{1} \mathrm{H}-\mathrm{NMR}$ (DMSO$\left.d_{6}\right) \delta: 10.07(1 \mathrm{H}, \mathrm{s}), 8.15(2 \mathrm{H}, \mathrm{dd}, J=7.7,1.3 \mathrm{~Hz}), 7.76(1 \mathrm{H}, \mathrm{tt}$, $J=7.7,1.3 \mathrm{~Hz}), 7.64(1 \mathrm{H}, \mathrm{d}, J=8.7 \mathrm{~Hz}), 7.62(2 \mathrm{H}, \mathrm{t}, J=7.7 \mathrm{~Hz})$, $6.77(1 \mathrm{H}, \mathrm{d}, J=2.7 \mathrm{~Hz}), 6.59(1 \mathrm{H}, \mathrm{dd}, J=8.7,2.7 \mathrm{~Hz}) \cdot{ }^{13} \mathrm{C}-\mathrm{NMR}$ $\left(\right.$ DMSO- $\left.d_{6}\right) \delta: 163.7,158.8,151.6,138.9,134.3,129.9,129.1$, 128.7, 115.9, 111.0, 77.4. High resolution (HR)-EI-MS: $\mathrm{m} / \mathrm{z}$ 339.9593 (Calcd for $\mathrm{C}_{13} \mathrm{H}_{9} \mathrm{IO}_{3}: 339.9597$ ).

2-Iodo-5-(1,1-dimethyl-2-propynyloxy)phenyl Benzoate (5) To a solution of $\mathbf{1 0}(0.22 \mathrm{~mL}, 2.27 \mathrm{mmol})$ and DBU $(0.40 \mathrm{~mL}, 2.67 \mathrm{mmol})$ in $\mathrm{CH}_{3} \mathrm{CN}(1.0 \mathrm{~mL})$ at $0^{\circ} \mathrm{C}$, TFAA $(0.32 \mathrm{~mL}, 2.30 \mathrm{mmol})$ was added and stirred for $1 \mathrm{~h}$ to prepare a solution of 9. In another flask, a solution of $7(680.4 \mathrm{mg}$, $2.00 \mathrm{mmol})$ and $\mathrm{CuCl}_{2} \cdot 2 \mathrm{H}_{2} \mathrm{O}(1.0 \mathrm{mg}, 0.006 \mathrm{mmol})$ in $\mathrm{CH}_{3} \mathrm{CN}$ $(1.5 \mathrm{~mL})$ was treated with $\mathrm{DBU}(0.40 \mathrm{~mL}, 2.67 \mathrm{mmol})$ at $0^{\circ} \mathrm{C}$ for $5 \mathrm{~min}$. To this solution, the above mixture of 9 was added at $0^{\circ} \mathrm{C}$ and stirred at $0^{\circ} \mathrm{C}$ for $75 \mathrm{~min}$. The whole was poured 
into $\mathrm{H}_{2} \mathrm{O}(7.5 \mathrm{~mL})$ and extracted with AcOEt $(3 \times 15 \mathrm{~mL})$. The combined organic layer was washed with $1 \mathrm{~N} \mathrm{HCl}, 1 \mathrm{~N} \mathrm{KOH}$ and brine (each $1 \times 5 \mathrm{~mL}$ ) and dried over $\mathrm{Na}_{2} \mathrm{SO}_{4}$. The solvent was evaporated in vacuo and the residue was purified over $\mathrm{SiO}_{2}$ column chromatography (AcOEt $-n$-hexane $=5: 95$ ) to give 5 (491.7 mg, a colorless oil, 61\%).

IR: $1739 \mathrm{~cm}^{-1} .{ }^{1} \mathrm{H}-\mathrm{NMR} \delta: 8.27(2 \mathrm{H}$, dif. $\mathrm{d}, J=8.4 \mathrm{~Hz}), 7.72$ $(1 \mathrm{H}, \mathrm{d}, J=8.8 \mathrm{~Hz}), 7.67(1 \mathrm{H}, \mathrm{tt}, J=7.6,1.1 \mathrm{~Hz}), 7.54(2 \mathrm{H}, \mathrm{t}$, $J=7.6 \mathrm{~Hz}), 7.19(1 \mathrm{H}, \mathrm{d}, J=2.7 \mathrm{~Hz}), 6.94(1 \mathrm{H}, \mathrm{dd}, J=8.8,2.7 \mathrm{~Hz})$, $2.61(1 \mathrm{H}, \mathrm{s}), 1.67(6 \mathrm{H}, \mathrm{s}) .{ }^{13} \mathrm{C}-\mathrm{NMR} \delta: 164.1,156.8,151.4$, 138.7, 133.8, 130.5, 129.2, 128.6, 120.5, 116.3, 85.2, 81.6, 74.7, 72.9, 29.5. HR-EI-MS: $m / z 406.0082$ (Calcd for $\mathrm{C}_{18} \mathrm{H}_{15} \mathrm{IO}_{3}$ : 406.0066).

6-Iodo-2,2-dimethyl-2H-chromen-5-ol (13) 5 (396.8 mg, $0.977 \mathrm{mmol})$ was dissolved in $N, N$-diethylaniline $(0.39 \mathrm{~mL})$ and heated at $190^{\circ} \mathrm{C}$ for $30 \mathrm{~min}$. The whole was diluted with AcOEt $(15 \mathrm{~mL})$ and washed with $5 \% \mathrm{HCl}(1 \times 1.5,1 \times 1.0 \mathrm{~mL})$ and brine $(1 \times 1.0 \mathrm{~mL})$ and dried over $\mathrm{Na}_{2} \mathrm{SO}_{4}$. The solvent was evaporated in vacuo to give a residue $(450.5 \mathrm{mg})$. A portion of the residue $(231.0 \mathrm{mg})$ was dissolved in methanolic $\mathrm{KOH}$ $(0.54 \mathrm{M}, 2.0 \mathrm{~mL}, 1.08 \mathrm{mmol})$ and stirred at $\mathrm{rt}$ for $50 \mathrm{~min}$. The reaction mixture was evaporated and the residue was dissolved in $\mathrm{H}_{2} \mathrm{O}(1.0 \mathrm{~mL})$ and washed with $n$-hexane $(1.0 \mathrm{~mL})$. The organic layer was extracted with $1 \mathrm{~N} \mathrm{KOH}(0.5 \mathrm{~mL})$ and the combined aqueous layer was acidified with $5 \% \mathrm{HCl}$ and extracted with AcOEt $(3 \times 10 \mathrm{~mL})$. The combined organic layer was washed with brine $(1 \times 3 \mathrm{~mL})$ and dried over $\mathrm{Na}_{2} \mathrm{SO}_{4}$. The solvent was evaporated in vacuo and the residue was purified over $\mathrm{SiO}_{2}$ column chromatography (AcOEt- $n$-hexane $=$ $1: 99-15: 85)$ to give $\mathbf{1 3}(92.3 \mathrm{mg}$, a colorless oil, $61 \%)$ and $\mathbf{1 4}$ (31.8 mg, colorless solids, $21 \%$ ).

IR: $3438 \mathrm{~cm}^{-1} .{ }^{1} \mathrm{H}-\mathrm{NMR} \delta: 7.32(1 \mathrm{H}, \mathrm{d}, J=8.5 \mathrm{~Hz}), 6.66$ $(1 \mathrm{H}, \mathrm{d}, J=10.0 \mathrm{~Hz}), 6.26(1 \mathrm{H}, \mathrm{dd}, J=8.5,0.7 \mathrm{~Hz}), 5.59(1 \mathrm{H}, \mathrm{d}$, $J=10.0 \mathrm{~Hz}), 5.22(1 \mathrm{H}, \mathrm{s}), 1.42(6 \mathrm{H}, \mathrm{s}) .{ }^{13} \mathrm{C}-\mathrm{NMR} \delta: 154.6,150.1$, $136.5,129.8,117.1,111.5,109.7,76.2,74.9,27.8$. Low resolution (LR)-EI-MS: $m / z$ (\%) $302\left(\mathrm{M}^{+}, 22\right), 287$ (100), 252 (52), 250 (32), 235 (25), 233 (16), 219 (16), 217 (10), 160 (41), 105 (33).

6-Iodo-2,2-dimethyl-2H-chromen-5-yl Trifluoromethanesulfonate (4) To a solution of $13(1.80 \mathrm{~g}, 5.95 \mathrm{mmol})$ and $\mathrm{Et}_{3} \mathrm{~N}(1.70 \mathrm{~mL}, 12.2 \mathrm{mmol})$ in $\mathrm{CH}_{2} \mathrm{Cl}_{2}(14.0 \mathrm{~mL}), \mathrm{Tf}_{2} \mathrm{O}$ $(1.25 \mathrm{~mL}, 7.43 \mathrm{mmol})$ was added at $-78^{\circ} \mathrm{C}$. After the solution was stirred at $-78^{\circ} \mathrm{C}$ for $1.5 \mathrm{~h}, \mathrm{H}_{2} \mathrm{O}(6.0 \mathrm{~mL})$ was added and the mixture was warmed to $\mathrm{rt}$. The whole was poured into $\mathrm{H}_{2} \mathrm{O}(6.0 \mathrm{~mL})$ and extracted with $\mathrm{Et}_{2} \mathrm{O}(1 \times 100,2 \times 50 \mathrm{~mL})$. The combined organic layer was washed with brine $(1 \times 10 \mathrm{~mL})$ and dried over $\mathrm{Na}_{2} \mathrm{SO}_{4}$. The solvent was evaporated in vacuo and the residue was purified over $\mathrm{SiO}_{2}$ column chromatography (AcOEt- $n$-hexane $=1: 99-3: 97)$ to give a pale yellow oil $(2.42 \mathrm{~g})$, which was dissolved in pentane. The solution was cooled to $-78^{\circ} \mathrm{C}$. The precipitates were collected by filtration and dried under reduced pressure to give 4 (2.21 g, colorless needles, $86 \%$ ).

mp: $49-50{ }^{\circ} \mathrm{C}$. IR: no characteristic absorption. ${ }^{1} \mathrm{H}-\mathrm{NMR} \delta$ : $1.45(6 \mathrm{H}, \mathrm{s}), 5.77(1 \mathrm{H}, \mathrm{d}, J=10.1 \mathrm{~Hz}), 6.56(1 \mathrm{H}, \mathrm{d}, J=10.1 \mathrm{~Hz})$, $6.61(1 \mathrm{H}, \mathrm{dd}, J=8.6,0.8 \mathrm{~Hz}), 7.57(1 \mathrm{H}, \mathrm{d}, J=8.6 \mathrm{~Hz}) .{ }^{13} \mathrm{C}-\mathrm{NMR}$ $\delta: 27.5,76.7,77.4,116.4,117.4,118.4,118.5\left(\mathrm{q}, J_{\mathrm{C}-\mathrm{F}}=321.1 \mathrm{~Hz}\right)$, 133.0, 139.4, 145.2, 154.6. HR-EI-MS: $\mathrm{m} / z 433.9299$ (Calcd for $\left.\mathrm{C}_{12} \mathrm{H}_{10} \mathrm{~F}_{3} \mathrm{IO}_{4} \mathrm{~S}: 433.9297\right)$.

9-(Benzyloxy)-3,3,8-trimethyl-7-(triisopropylsilyloxy)-3Hbenzo $[f]$ chromen-10-ol (15) and 8-(Benzyloxy)-3,3,9-trimethyl-10-(triisopropylsilyloxy)-3H-benzo $[f]$ chromen-7-ol
(16) To a solution of $4(138.3 \mathrm{mg}, 0.319 \mathrm{mmol})$ and furan $3(138.0 \mathrm{mg}, 87 \% \mathrm{w} / \mathrm{w}$ purity as a mixture with TIPSOH, $0.333 \mathrm{mmol})$ in THF $(4.0 \mathrm{~mL}), n$-BuLi $(1.11 \mathrm{~m}$ in $n$-hexane, $0.49 \mathrm{~mL}, 0.544 \mathrm{mmol}$ ) was added at $-78^{\circ} \mathrm{C}$. After the solution was stirred at $-78^{\circ} \mathrm{C}$ for $15 \mathrm{~min}$, further $n$-BuLi $(0.09 \mathrm{~mL}$, $0.100 \mathrm{mmol}$ ) was added and stirred at same temperature for further $20 \mathrm{~min}$. The $\mathrm{H}_{2} \mathrm{O}(4.0 \mathrm{~mL})$ was added and the mixture was warmed to rt. The whole was extracted with AcOEt $(3 \times 10 \mathrm{~mL})$ and the combined organic layer was washed with $\mathrm{H}_{2} \mathrm{O}$ and brine (each $1 \times 2 \mathrm{~mL}$ ) and dried over $\mathrm{Na}_{2} \mathrm{SO}_{4}$. The solvent was evaporated in vacuo and the residue was purified over $\mathrm{SiO}_{2}$ column chromatography (AcOEt- $n$-hexane $=$ $1: 99-15: 85)$ to give $15(29.3 \mathrm{mg}$, a reddish brown oil, $18 \%)$ and $\mathbf{1 6}(53.8 \mathrm{mg}$, a yellow oil, $33 \%)$.

15: IR: $3380 \mathrm{~cm}^{-1} .{ }^{1} \mathrm{H}-\mathrm{NMR} \delta: 1.11(18 \mathrm{H}, \mathrm{d}, J=7.6 \mathrm{~Hz})$, 1.33-1.41 (3H, m), 1.47 (6H, s), $2.39(3 \mathrm{H}, \mathrm{s}), 4.89(2 \mathrm{H}, \mathrm{s})$, $5.56(1 \mathrm{H}, \mathrm{d}, J=10.2 \mathrm{~Hz}), 5.94(1 \mathrm{H}, \mathrm{s}), 6.93(1 \mathrm{H}, \mathrm{d}, J=9.2 \mathrm{~Hz})$, $7.39-7.45(3 \mathrm{H}, \mathrm{m}), 7.48(2 \mathrm{H}$, dd-like, $J=7.9,1.7 \mathrm{~Hz}), 7.78$ $(1 \mathrm{H}, \mathrm{d}, J=10.2 \mathrm{~Hz}), 7.84(1 \mathrm{H}, \mathrm{d}, J=9.2 \mathrm{~Hz}) .{ }^{13} \mathrm{C}-\mathrm{NMR} \delta: 11.6$, $14.2,18.1,27.4,74.9,75.7,114.1,1115.1,17.2,119.2,122.3$, $122.9,124.0,127.1,128.2,128.6,128.9,136.8,139.5,141.9$, 144.3, 151.2. HR-EI-MS m/z: 518.2828 (Calcd for $\mathrm{C}_{32} \mathrm{H}_{42} \mathrm{O}_{4} \mathrm{Si}$ : 518.2852).

16: IR: $3357 \mathrm{~cm}^{-1}$. ${ }^{1} \mathrm{H}-\mathrm{NMR} \quad \delta$ : $0.85-0.96(21 \mathrm{H}, \mathrm{m}), 1.43$ $(3 \mathrm{H}, \mathrm{s}), 1.49(3 \mathrm{H}, \mathrm{s}), 1.95(3 \mathrm{H}, \mathrm{s}), 5.11(2 \mathrm{H}, \mathrm{s}), 5.69(1 \mathrm{H}$, d, $J=10.5 \mathrm{~Hz}), 6.90(1 \mathrm{H}, \mathrm{dd}, J=8.6,0.7 \mathrm{~Hz}), 7.18(1 \mathrm{H}, \mathrm{br})$, 7.29-7.36 (4H, m), 7.45 (2H, dd-like, $J=7.9,1.7 \mathrm{~Hz}), 7.96(1 \mathrm{H}$, d, $J=8.6 \mathrm{~Hz}) .{ }^{13} \mathrm{C}-\mathrm{NMR} \delta: 11.4,13.6,17.8,18.0,27.9,28.6$, $73.8,76.5,101.4,118.5,120.5,125.3,128.2,128.3,128.4$, $128.8,130.5,137.2,137.4,141.1,149.0,158.2,179.5$. HR-ESIMS: $m / z$ 517.2772 [(M-H) ${ }^{+}$, Calcd for $\mathrm{C}_{32} \mathrm{H}_{41} \mathrm{O}_{4} \mathrm{Si}$ : 517.2774].

9-Hydroxy-3,3,8-trimethyl-7,10-dihydro-3H-benzo[f $]$ chromene-7,10-dione (1) To a solution of 15 (28.9 mg, $0.0557 \mathrm{mmol})$ in methanol $(1.1 \mathrm{~mL})$, aqueous $\mathrm{FeCl}_{3}(0.82 \mathrm{M}$, $0.15 \mathrm{~mL}, 0.123 \mathrm{mmol}$ ) was added at $\mathrm{rt}$ and the whole was stirred at $\mathrm{rt}$ for $50 \mathrm{~min}$. The mixture was poured into $\mathrm{H}_{2} \mathrm{O}$ $(2 \mathrm{~mL})$ and extracted with $\mathrm{CH}_{2} \mathrm{Cl}_{2}(1 \times 10,2 \times 5 \mathrm{~mL})$. The combined organic layer was washed with $\mathrm{H}_{2} \mathrm{O}$ and brine (each $1 \times 2 \mathrm{~mL}$ ) and dried over $\mathrm{Na}_{2} \mathrm{SO}_{4}$. The solvent was evaporated in vacuo to give crude $17(30.9 \mathrm{mg})$. A portion of the crude $17(30.2 \mathrm{mg})$ was dissolved in $\mathrm{CH}_{2} \mathrm{Cl}_{2}(2.7 \mathrm{~mL})$ and cooled to $-78^{\circ} \mathrm{C} . \mathrm{BCl}_{3}$ in heptane $(1.0 \mathrm{M}, 0.28 \mathrm{~mL}, 0.28 \mathrm{mmol})$ was added to the solution and stirred at $-78^{\circ} \mathrm{C}$ for $20 \mathrm{~min} . \mathrm{H}_{2} \mathrm{O}$ $(2.0 \mathrm{~mL})$ was added and the mixture was warmed to $\mathrm{rt}$. The whole was extracted with $\mathrm{CH}_{2} \mathrm{Cl}_{2}(1 \times 10,2 \times 5 \mathrm{~mL})$. The combined organic layer was washed with $\mathrm{H}_{2} \mathrm{O}$ and brine (each $1 \times 2 \mathrm{~mL}$ ) and dried over $\mathrm{Na}_{2} \mathrm{SO}_{4}$. The solvent was evaporated in vacuo and the residue was purified over $\mathrm{SiO}_{2}$ column chromatography (AcOEt $-n$-hexane $=5: 95-15: 85)$ to give $1(9.3 \mathrm{mg}$, orange solids, $63 \%$ ).

mp: $163-165^{\circ} \mathrm{C}$. IR: $3376,1642 \mathrm{~cm}^{-1}$. ${ }^{1} \mathrm{H}-\mathrm{NMR} \quad \delta: 1.47$ $(6 \mathrm{H}, \mathrm{s}), 2.06(3 \mathrm{H}, \mathrm{s}), 5.97(1 \mathrm{H}, \mathrm{d}, J=10.3 \mathrm{~Hz}), 7.07(1 \mathrm{H}, \mathrm{d}$, $J=8.5 \mathrm{~Hz}), 7.44(1 \mathrm{H}$, br s), $7.77(1 \mathrm{H}, \mathrm{d}, J=10.3 \mathrm{~Hz}), 7.98(1 \mathrm{H}$, d, $J=8.5 \mathrm{~Hz}) .{ }^{13} \mathrm{C}-\mathrm{NMR} \delta: 8.5,28.0,76.8,118.7,119.7,121.3$, $122.0,123.4$, 127.1, 128.7, 135.9, 153.3, 157.7, 183.3, 184.5. HREI-MS m/z: 270.0888 (Calcd for $\mathrm{C}_{16} \mathrm{H}_{14} \mathrm{O}_{4}: 270.0892$ ).

8-(Benzyloxy)-10-methoxy-3,3,9-trimethyl-10-(triisopropylsilyloxy)-7,10-dihydro-3H-benzo $[f]$ chromen-7-one (18) Methanol $(1.0 \mathrm{~mL})$ was added to a mixture of $\mathbf{1 6}(107.9 \mathrm{mg}$, $0.208 \mathrm{mmol})$ and DIB $(73.7 \mathrm{mg}, 0.229 \mathrm{mmol})$ and stirred at $\mathrm{rt}$ for $1 \mathrm{~h}$. Saturated aqueous $\mathrm{NaHCO}_{3}(1.0 \mathrm{~mL})$ was added and 
the whole was poured into $\mathrm{H}_{2} \mathrm{O}(1.0 \mathrm{~mL})$. The whole was extracted with AcOEt $(1 \times 10,2 \times 5 \mathrm{~mL})$. The combined organic layer was washed with $\mathrm{H}_{2} \mathrm{O}$ and brine (each $1 \times 2 \mathrm{~mL}$ ) and dried over $\mathrm{Na}_{2} \mathrm{SO}_{4}$. The solvent was evaporated in vacuo and the residue was purified over $\mathrm{SiO}_{2}$ column chromatography (AcOEt- $n$-hexane $=1: 99-9: 91)$ to give $\mathbf{1 8}(45.5 \mathrm{mg}$, a yellow oil, $40 \%$ ).

IR: $1658 \mathrm{~cm}^{-1}$. ${ }^{1} \mathrm{H}-\mathrm{NMR} \delta$ : $0.86-0.91(21 \mathrm{H}, \mathrm{m}), 1.43(3 \mathrm{H}, \mathrm{s})$, $1.45(3 \mathrm{H}, \mathrm{s}), 1.89(3 \mathrm{H}, \mathrm{s}), 2.62(3 \mathrm{H}, \mathrm{s}), 5.07(1 \mathrm{H}, \mathrm{d}, J=11.2 \mathrm{~Hz})$, $5.22(1 \mathrm{H}, \mathrm{d}, J=11.2 \mathrm{~Hz}), 5.65(1 \mathrm{H}, \mathrm{d}, J=10.5 \mathrm{~Hz}), 6.87(1 \mathrm{H}$, dd, $J=8.6,0.7 \mathrm{~Hz}), 7.35-7.28(3 \mathrm{H}, \mathrm{m}), 7.44-7.41(3 \mathrm{H}, \mathrm{m}), 7.95$ $(1 \mathrm{H}, \mathrm{d}, J=8.6 \mathrm{~Hz}) .{ }^{13} \mathrm{C}-\mathrm{NMR} \delta: 11.3,13.7,17.9,18.1,27.9,28.5$, $50.2,73.6,76.5,97.7,118.2,118.9,121.0,125.0,128.1,128.2$, 128.4, 128.9, 130.0, 137.4, 137.8, 141.6, 148.3, 158.1, 179.6. HRESIM-S: $549.3042\left[(\mathrm{M}+\mathrm{H})^{+}\right.$, Calcd for $\left.\mathrm{C}_{33} \mathrm{H}_{45} \mathrm{O}_{5} \mathrm{Si}: 549.3036\right]$.

8-Hydroxy-3,3,9-trimethyl-7,10-dihydro-3H-benzo $[f]$ chromene-7,10-dione (19) $\mathbf{1 8}(21.3 \mathrm{mg}, 0.0388 \mathrm{mmol})$ was subjected to debenzylation in the same condition from $\mathbf{1 7}$ to $\mathbf{1}$ (vide supra). The obtained residue was purified over $\mathrm{SiO}_{2}$ column chromatography (AcOEt $-n$-hexane $=5: 95-20: 80)$ to give 19 (10.2 mg, yellow solids, $97 \%$ ).

mp: $208-210^{\circ} \mathrm{C}$. IR: $3347,1646 \mathrm{~cm}^{-1} .{ }^{1} \mathrm{H}-\mathrm{NMR} \delta: 1.47(6 \mathrm{H}$, s), $2.05(3 \mathrm{H}, \mathrm{s}), 5.93(1 \mathrm{H}, \mathrm{d}, J=10.3 \mathrm{~Hz}), 7.00(1 \mathrm{H}, \mathrm{dd}, J=8.4$, $0.7 \mathrm{~Hz}), 7.27(1 \mathrm{H}, \mathrm{brs}), 7.82(1 \mathrm{H}, \mathrm{d}, J=10.3 \mathrm{~Hz}), 7.95(1 \mathrm{H}, \mathrm{d}$, $J=8.4 \mathrm{~Hz}$ ). ${ }^{13} \mathrm{C}-\mathrm{NMR} \quad \delta: 8.8,28.0,77.1,120.1,120.2,120.8$, $121.4,123.5,127.5,128.6,134.6,152.2,160.2,180.1,187.9$. HR-EIMS: 270.0887 (Calcd for $\mathrm{C}_{16} \mathrm{H}_{14} \mathrm{O}_{4}: 270.0892$ ).

Acknowledgments This work was partly supported by The Uehara Memorial Foundation and a Grant from Musashi- no Joshi-Gakuin.

\section{References and Notes}

1) Yang S. S., Cragg G. M., Newman D. J., Bader J. P., J. Nat. Prod., 64, 265-277 (2001).

2) Scott J. D., Williams R. M., Chem. Rev., 102, 1669-1730 (2002).

3) Herzon S. B., Woo C. M., Nat. Prod. Rep., 29, 87-118 (2012).

4) Cannon J. R., Joshi K. R., McDonald I. A., Retallack R. W., Sierakowski A. F., Wong L. C. H., Tetrahedron Lett., 2795-2798 (1975).

5) Decosterd L. A., Parsons I. C., Gustafson K. R., Cardellina II J. H., McMahon J. B., Cragg G. M., Murata Y., Pannell L. K., Steiner J. R., Clardy J., Boyd M. R., J. Am. Chem. Soc., 115, 6673-6679 (1993).

6) Katakawa K., Yonenaga D., Terada T., Aida N., Sakamoto A., Hoshino K., Kumamoto T., Heterocycles, 88, 817-825 (2014).

7) Example of regioselective Claisen rearrangement of propargyl ether of resolcinols; Box V. G. S., Burke B. A., McCaw C., Heterocycles, 12, 451-452 (1979).

8) Nicolet B. H., Sampey J. R., J. Am. Chem. Soc., 49, 1796-1801 (1927).

9) Godfrey Jr. J. D., Mueller R. H., Sedergran T. C., Soundararajan N., Colandrea V. J., Tetrahedron Lett., 35, 6405-6408 (1994).

10) Ding C. Z., Synth. Commun., 26, 4267-4273 (1996).

11) Application of platinum catalyst gave low selectivity $(1: 1)$. Example of catalystic cyclizaton of propargyl ether; Pastine S. J., Youn S. W., Sames D., Tetrahedron, 59, 8859-8868 (2003).

12) Yao T., Yue D., Larock R. C., J. Org. Chem., 70, $9985-9989$ (2005).

13) Hume P. A., Sperry J., Brimble M. A., Org. Biomol. Chem., 9, 5423-5430 (2011).

14) McDonald I. A., Simpson T. J., Sierakowski A. F., Aust. J. Chem., 30, 1727-1734 (1977).

15) Li C., Johnson R. P., Porco J. A. Jr., J. Am. Chem. Soc., 125, 50955106 (2003). 